\title{
Jorge de Lima poeta em movimento (Do "menino impossível" ao Livro de sonetos)
}

\author{
ALFREDO BOSI ${ }^{I}$
}

Para Ivan Vilela

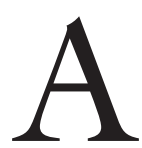

PRIMEIRA impressão que se tem ao percorrer o itinerário poético de Jorge de Lima é de uma extraordinária multiplicidade de temas e formas literárias. Poeta parnasiano na primeira juventude; modernista de cadências regionalistas nordestinas entre o final dos anos 1920 e início dos 1930; programadamente poeta religioso, cristão e bíblico, nos anos 1930 e 1940, com originais passagens pela poesia do negro; surrealista sui generis, entre barroco e simbolista, nos anos $1950 \ldots$

$\mathrm{O}$ intérprete que desejar compreender esses diversos campos existenciais e formais deverá perguntar-se: qual a gênese existencial de cada um deles? E, em seguida: haveria uma possível unidade de sentido subjacente a esse imenso conjunto de expressões poéticas?

Aqui entramos na esfera das hipóteses hermenêuticas. Mas é preciso arriscar e talvez nos ajude uma aproximação inicial com a história da literatura brasileira anterior e posterior à difusão do modernismo no Nordeste. O jovem poeta parnasiano dos XIV Alexandrinos, eleito príncipe dos poetas alagoanos, vive uma atmosfera literária provinciana, epigônica. A linguagem é convencional, toda emprestada dos assuntos e fraseios de uma escrita que se repete entre escolar e sentenciosa, sem um sopro de experiência pessoal. Daí o significado forte de salto qualitativo que foi a composição de "O mundo do menino impossível", publicado em 1927. A rigor, parecia impossível ao autor, já homem feito, que um menino bem nascido pudesse ter saído do mundo dos brinquedos caros, artificiais, de marca estrangeira, e ter imerso a memória nas coisas simples do cotidiano da sua infância. No caso, a conversão cultural e a conversão existencial coincidiram, o que tornou efetiva a primeira mutação poética.

Mas o que aconteceu, de fato, foi a drástica substituição dos chavões literários por uma entrega do adulto a lembranças infantis. É preciso ler as Minhas memórias e as entrevistas de Jorge de Lima para entender a sede de renovação que se fez sentir também no Nordeste ao longo dos anos 1920 (Lima, 1958a, p.98-157). 
Esse movimento na direção do passado real, vivo, concreto, e não de um passado construído pela cultura hegemônica, se fez mediante a evocação por imagens. O ritmo destas já não será marcado pela isocronia parnasiana, de que o metro alexandrino dos sonetos dera exemplo. Trata-se agora do ritmo processional (a certa altura, o poeta invocará a presença de Whitman), que se desdobra à medida que as imagens se seguem na memória. Uma sensível dose de realismo entra na composição deste e de outros poemas enraizados na biografia alagoana de Jorge de Lima. Daí em diante, a sua poesia seria um afloramento de figuras reais ou imaginárias que o perseguirão até a criação de Invenção de Orfeu. Reais ou imaginárias: os brinquedos da infância, posto que inventados, foram absolutamente reais, mas do mundo do menino também se diz que foi tirado "do nada", como parece acontecer às vezes durante a vivência do sonho: "O menino poisa a testa - e sonha dentro da noite quieta - da lâmpada apagada - com o mundo maravilhoso - que ele tirou do nada".

É um momento fecundo a sintonia deste Jorge de Lima com a eclosão do romance nordestino do período que vai do aparecimento de $A$ bagaceira (1928) de José Américo de Almeida aos primeiros anos da década seguinte. Os nomes formam constelação: Raquel de Queiroz, com O quinze; José Lins do Rego, com o Menino de engenho, primeiro lance feliz seguido de todo um ciclo de aprofundamento da experiência de uma infância vivida em clima de patriarcalismo decadente; Jorge Amado, estreando com O pais do carnaval, igualmente passo inicial de uma visão entre romântica e naturalista da sua Bahia... As obras-primas não tardariam a chegar: São Bernardo, em 1934, e Vidas secas, em 1938, de Graciliano Ramos.

O conjunto das obras, apesar da diferença de qualidade estética e dos desníveis de alcance ideológico, chama a atenção pelo que significava de reconhecimento de uma identidade física e social marginalizada: o Nordeste em face da crescente hegemonia do capitalismo industrial paulista. Não cabe aqui fazer o mapeamento das vertentes ideológicas em presença. A grande síntese de Gilberto Freyre, Casa grande \& senzala, de 1933, deu substância a um pensamento entre realista (pela riqueza ímpar de observação) e conservador, pela apologia do estilo tradicional de vida no engenho. Do lado oposto, a exposição da pobreza em toda a região, ferida pela sobrevivência de uma semiescravidão, serviu para denunciar as iniquidades do sistema econômico e político, o que alentou uma posição de esquerda em alguns núcleos de intelectuais da província.

Nessa rede de contrastes, a poesia regional de Jorge de Lima oscilou entre o saudosismo da paisagem natural e social vivida na infância e a denúncia da opressão que pesava sobre o negro, o cambembe e o proletário. Denúncia que se mostraria lancinante no seu romance Calunga, publicado em 1935, quadro sem retoques da miséria e da violência dominante no interior de Alagoas. Daí vem o duplo registro da escrita poética feita ora de evocação, ora de invocação. 


\section{Evocação e invocação}

A evocação dos lugares é aberta a referências que cumprem a função de ladrilhos de um mosaico entre pitoresco e sentimental: a estrada de ferro, então gerida pela GBWR, título de um poema tipicamente processional; os rios, "caminhos de minha terra", as enchentes, as lagoas, a casa paterna fronteando a Serra da Barriga e os seus quilombos, os bairros de Salvador, o circo, as igrejinhas, tudo permeado de nostalgia e afeto. Predomina a sintaxe linear, parataxe que dá continuidade ao que seria, para o leitor, pura enumeração aparentemente aleatória, mas na verdade penetrada de um calor difuso que tudo unifica.

Uma questão epistemológica talvez não fosse aqui de todo impertinente: seria esse painel de imagens construído na base de associações já feitas entre "conteúdos" estocados na memória do adulto, ou estamos diante de uma ativa intencionalidade da consciência, para usar da linguagem da fenomenologia de Husserl e Sartre, quando recusam a hipótese de uma imaginação passiva, que se alimentaria tão só, e necessariamente, de estímulos externos já prontos? (Sartre, 1965, p.139-59). Pela teoria da intencionalidade da consciência imagística, o mosaico é uma escolha poética deliberada, uma vontade-de-estilo, e não uma reação automática a determinados estímulos. A ser verdadeira, essa compreensão da imagem dá ao memorialismo dos poemas nordestinos de Jorge de Lima uma objetividade complexa, entranhada de subjetividade.

Ao lado da evocação, em terceira pessoa, há a invocação, que pode ser definida como lembrança com uso da segunda pessoa. São situações e figuras extraídas empenhadamente da memória para entrarem em regime de presentificação. O exemplo forte é o admirável "Essa negra Fulô", que abre os Novos poemas. Não por acaso, nesse texto, que virou antológico, Jorge de Lima trabatha motivos que seriam explorados nos Poemas negros, publicados anos depois.

Tudo é belo e intenso na escrita e na diç̧ão oral do poema. Fulô é flor negra, como trigueira será a rosa da "Ancila negra". E é a força da sua presença ubíqua na vida da Sinhá e do Sinhô que move o apelo reiterado: "Ó Fulô! Ó Fulô!". O vocativo ao mesmo tempo chama e potencia a imagem da escrava, que servia "no banguê dum meu avô", e dá lugar à fala narrativa, outra conquista do poema. Cada chamamento, sempre vazado em redondilhos maiores, familiares à poesia popular luso-nordestina, remete a uma relação estreita da mucama com a intimidade corporal da senhora. Fulô faz a cama da Sinhá, penteia-lhe os cabelos, ajuda-a a despir-se, abana seu corpo suado, coça a sua coceira, cata cafuné, balança a rede e, para fazê-la dormir, conta-lhe histórias. Nessa altura o poema incorpora a recitação de antigos versos folclóricos. Primeiro, duas trovas encadeadas contando a lenda da princesa que possuía um vestido com os peixinhos do mar trazendo, na coda, a quadrinha que dá fecho e abre a porta para uma nova narrativa ("Entrou na perna de um pato - saiu na perna de um pinto - o Rei-Sinhô me mandou - que vos contasse mais cinco"). Depois, a quadra de embalo para fazer dormir os meninos: "Minha mãe me penteou - minha ma- 
drasta me enterrou - pelos figos da figueira - que o Sabiá beliscou”. Prenúncio dos castigos que a Sinhá vai infligir à mucama?

O último movimento do poema é o reverso cruel da intimidade. Os objetos de adorno e luxo da sinhá somem, a culpa recai sobre Fulô. A proximidade dos corpos parece ter excitado o sadismo com que a senhora exercerá o poder sobre a escrava. A punição vai em crescendo, passa do açoite do feitor ao açoite do próprio Sinhô, que sucumbirá ao desejo de possuir a escrava, enfim acusada pela Sinhá de ter-lhe roubado o marido...

Assim, a invocação da figura da mucama, acorde lírico inicial, se desdobrou em narrativa feita de situações de intimidade (cama, rede, sono, cafuné...), deteve-se na (re)citação da trova popular, para, enfim, reverter em acusação de roubo, com toda a carga perversa trazida pela iniquidade da assimetria social. Em suma, o que nos deu o poeta? Imagens intencionais da memória com função mimética, expressão de vivências sensuais ou agressivas e escrita configurada pelo metro popular em simetrias rítmicas e melódicas.

Se "O mundo do menino impossível" significou a mudança consciente da poética de Jorge de Lima para o espírito e a letra do modernismo, "Essa negra Fulô" pode ser considerado a pedra angular de uma construção do que viria ser a chamada poesia negra, produzida ao longo dos anos 1930 e 1940, em consonância com um movimento poético afro-hispânico, que se consolidava nessas décadas.

Remeto o leitor ao estudo abrangente de Vagner Camilo (2012-2013), que reconstrói o contexto (literário e ideológico) afro-americano e, em particular, afro-cubano em que se inserem parcialmente os Poemas negros.

Creio que o procedimento de invocação, pela sua tendência individualizante, tenha sido um dos recursos mais fecundos da poesia negra de Jorge de Lima, na medida em que dele emergem seres humanos na sua complexa fisionomia de escravos e homens e mulheres portadores de uma tradição ao mesmo tempo vigorosa e recalcada. Chamá-los a ter presença no corpo da poesia culta é, apesar dos riscos ideológicos que essa operação comporta, um projeto ético e estético de sobrevivência, quando não de resistência.

Os exemplos não são poucos. Ainda em Novos poemas: "Serra da Barriga" ("Te vejo na casa em que nasci. Que medo danado de negro fujão!"), "Comidas" ("Iaiá me coma/Sou quimbombô; Bahia, estas comidas têm mandinga"); "Inverno" ("Zefa, chegou o inverno!"); "Diabo brasileiro" ("Diabo brasileiro, quero saber quanto dá/ a dezena do carneiro"); "Joaquina Maluca" ("Joaquina maluca, você ficou lesa"); "Meus olhos" ("Nossa Senhora, minha madrinha/tu vês as coisas verdes, não é?").

Nordeste, terra de São Sol!: "Poema de Natal" ("Ó meu Jesus"); "Ave Maria" ("Boa tarde, ó meu caminho estreito"); "Poema relativo" ("Vem, ó bem amada"), "Mulher proletária" ("Mulher proletária/única fábrica/que o operário tem (fábrica de filhos)/tu..."); "Poema à irmã" (“Ó irmã/agora que 
as noites vêm cedo"); "Poema à bem-amada" ("Amada, não penses"); "Poema a Marcel Proust" ("Ó meu petit Proust”); "Poema à Pátria" ("Ó grande país”).

Enfim, nos Poemas negros: "Banguê" ("Cadê você, meu país do Nordeste"); "Democracia” ("Ó Whitman”); “Ancila negra” ("Há ainda muita coisa a recalcar/Celidônia, ó linda moleca ioruba"); "Orambá é batizado" ("Pela fé de Zumbi te digo"); "Poema de encantação" ("Arraial d'Angola de Paracatu"); "Janaína” (“... Janaína, dá licença”); "Xangô" [invocação indireta]; "Olá! Negro" ("Os netos de teus mulatos e de teus cafuzos").

Mediante o vocativo, ou apóstrofe, a linguagem move-se no regime exclamativo, que aproxima o sujeito do objeto, já então subjetivado enquanto interlocutor trazido pela voz lírica. Se a evocação conserva sempre alguma distância entre o memorialista e a figura lembrada, a invocação convoca a presença do outro, enlaçando-o, o que pode ser um primeiro passo para a identificação, virtual passagem para o estado de transe.

Essa profunda sensação de empatia do poeta com figuras de ex-escravos que povoaram os seus verdes anos parece-me ter entrado na gênese da sua poesia religiosa, surreal ou hermética. O processo semântico abrangente chama-se, aqui, presentificação. Que pode envolver explicitamente o eu lírico, como em "Ancila negra", "Poema da encantação", "Rei é Oxalá, Rainha é Iemanjá" e na cadência final de "Janaína", ou objetivar-se na ação da entidade sagrada, como em "Benedito Calunga", "Quando ele vem", "Xangô", e na própria invocação do negro, que se dá em "Olá, Negro!".

Vejo em "Ancila negra", a obra-prima dos Poemas negros, uma sutil combinação de imagem evocada e imagem invocada. A terceira pessoa em regime impessoal do verbo haver ("Há") abre o poema com um acorde reflexivo que ressoará, quase bordão, em mais de uma estrofe: "Há ainda muita coisa a recalcar", seguido do nome-vocativo e de seu aposto, "Celidônia, ó linda moleca ioruba". A alternância (ela/tu) prossegue. A terceira pessoa enunciada pela desinência verbal do passado (embalou, acompanhou, contou) ao mesmo tempo se conserva e resvala para a esfera da memória até ceder à marcação da primeira pessoa: "que embalou minha rede", "me acompanhou para a escola, - me contou histórias de bichos - quando eu era pequeno, - muito pequeno mesmo".

A partir da segunda estrofe, feita a apresentação evocativa, o poeta trabalha empenhadamente as formas da presença da moleca ioruba nas entranhas da sua vida de menino nordestino neto de senhores de engenho. A condição psicológica do recalque é explícita no refrão, mas não oblitera, antes provoca, a pulsão da memória afetiva, que lateja em todo o poema. O desejo da presença é força motriz que nada consegue reprimir. Daí a continuidade, tão bem marcada pelo gerúndio, das carícias de Celidônia, "as tuas mãos negras me alisando - os teus lábios roxos me bubuiando, quando eu era pequeno, - muito pequeno mesmo". Celidônia, nome que traz em si a promessa de um dom do céu. 
Da profundidade do afeto nasce a palavra de encantamento: "ó linda mucama negra", beleza que as metáforas exprimem em versos de amor e dor: "carne perdida, - noite estancada, - rosa trigueira, - maga primeira". Por que perdida, por que estancada? O canto da beleza descanta sinais de morte. É o que a quarta estrofe dá em cadência narrativa:

Há muita coisa a recalcar e esquecer: / o dia em que te afogaste / sem me avisar que ias morrer, / negra fugida na morte, / contadeira de histórias do teu reino, / anjo degredado para sempre, / Celidônia, Celidônia, Celidônia!

De novo, a ingrata obsessão de reprimir, até o limite do esquecimento, o que no entanto está doridamente presente na alma do adulto que tudo lembra. A morte de Celidônia no fundo das águas revela, num átimo, a sua condição de negra fugida e para sempre exilada do seu reino - de onde ela trouxera histórias para contá-las ao menino pequeno, muito pequeno mesmo.

O fecho do poema leva o pensamento à suspensão do tempo. "Nunca mais" e "para sempre" são expressões incisivas de um presente pleno de sentido: som e, mais que som, ressoo de um sino ouvido pelo memorialista parado na infância, imerso no encantamento do sono, para sempre.

Nem sempre a presentificação da imagem conjurada se faz em primeira pessoa. A objetivação da figura de Benedito Calunga, no poema homônimo, anuncia o quase-transe que é o banzo do fiel tomado por Xangô.

O nome já diz bastante do sincretismo que preside a religiosidade afro-nordestina: Benedito, homem bendito e bento como o santo lendário, padrinho celeste de batismo de tantos e tantos cativos e seus descendentes; Calunga, palavra de várias denotações, aqui provavelmente designando o negro pobre, o fiel sem eira nem beira, mas, em geral, pertencente à falange de Iemanjá (calunga também significa "mar"...). De todo modo, quando o nome "calunga" se reporta a alguma entidade secundária, só excepcionalmente recebe culto particular. Essa carência de força própria leva a entender o estado de derrelicção que marca no poema a figura de Benedito Calunga. Fraco, ele é avesso ao mal exorcizado nas figuras tenebrosas do papa-fumo, do pé de garrafa, do minhocão. Cativo sem amparo, foi seviciado pelo senhor branco que o ferrou como gado e o atou ao lumbambo.

Significativamente, o calunga Benedito não se entregou à sedutora Iemanjá, mas tão somente a Xangô, rei potente de raios e tempestades, cujo banzo (mais que tristeza, paixão) o alforriou para sempre e o amuxilou, isto é, dele fez portador da vara listrada de preto e branco, o ixã, que afugenta os espíritos impertinentes.

Quer-me parecer que tanto na história da moleca ioruba como na do calunga há sugestão de uma volta dos cativos ao seu reino de origem, mundo de entidades protetoras, às quais eles pertencem ou pela entrega à morte ou pela paixão da saudade, o banzo. No breve poema Maria Diamba, a escrava "só diante da ventania/ que ainda vem do Sudão;/falou que queria fugir/dos senhores e das judiarias deste mundo/para o sumidouro". 
A expressão veemente dos poderes sobrenaturais que levam ao transe ou à possessão se reconhece nos versos arroubados do poema "Quando ele vem". O ritmo beira a alucinação em movimento. Quem vem no vento será um orixá, cuja presença irrompe no meio dos homens e os toma de assalto ensandecendo-os. Uma análise rítmica e fonética revelaria toda a riqueza dessa verdadeira tempestade sonora, provavelmente uma das mais expressivas da dicção afro-nordestina brasileira.

A entidade ao mesmo tempo zune como o vento, devora quanto pode das iguarias baianas, alagoanas, pernambucanas... (caruru de peixe, efó de inhame, ogudé de banana, olubó de macaxeira, pimenta malagueta...), mas sobretudo apodera-se das almas dos seus crentes de tal modo que "Quando ele chega, tudo fica banzando à toa". De novo, como na história de Benedito Calunga, o banzo conota um estado de corpo e de alma que arrasta ao delírio, à autodestruição, à luxúria desenfreada. Tristeza turva que se assemelha à perda da graça, tentação de pecado mortal, em termos de devoção cristã, pela cega violência que desencadeia nos sentimentos e atos dos que a experimentam.

A intuição do caráter metafisicamente negativo do Mal como privação do bem e do ser (definição que lhe deu a teologia, de Agostinho a Tomás de Aquino) reponta na imagem do "oco do mundo", o vazio abissal de onde "ele" vem: "Donde é que ele vem?/Vem de Oxalá, vem de Oxalá/vem do oco do mundo/ vem do assopro de Oxalá/ vem do oco do mundo". Mas é um vazio esse oco do mundo que não implica a ausência da divindade, antes professa abertamente a sua presença originária atribuindo-lhe o nome sagrado de Oxalá, o criador e procriador. Que o sopro de Oxalá arranque do oco do mundo ventos destruidores, e seja, ao mesmo tempo, o orixá da criação, dá o que pensar, no caso, faz pensar no caráter dramaticamente contraditório de todas as forças naturais e sobrenaturais.

Poemas negros tem por fecho "Olá, Negro!": invoca as gerações descendentes de escravos e exalta a força de alma de um povo capaz de redimir generosamente a opressão a que o branco o submeteu durante séculos. Aqui não se trata de glosar o discurso neutro e conciliante da "contribuição" do negro à formação do homem brasileiro. Aqui a imagem da iniquidade irrompe com todas as letras: "a raça que te enforca, enforca-se de tédio, negro".

O escravo aparece em suas múltiplas figuras: "Pai-João, Mãe-negra, Fulô, Zumbi, negro-fujão, negro cativo, negro rebelde, negro cabinda, negro congo, negro ioruba", e em seus múltiplos lugares de eito: "negro que foste para o algodão dos U.S.A., - para os canaviais do Brasil”. Mas a nota original do poema incide no poder transformador que exerce sobre "a alma branca cansada de todas as ferocidades" a alegria que emana dos jazzes e a gama de sentimentos expressos nos blues, songs, lundus. O riso franco, "a tua gargalhada que vem vindo", junto com a música, vem iluminar as noites dos brancos. Essa é a figura que remata o poema, que poderá ser lido e contestado como ideologia ou aceito como esperançosa contraideologia, opções contrastantes que comprovariam a riqueza de significações da linguagem poética. 


\section{Poesia bíblica e cristã}

A biografia de Jorge de Lima e do seu dileto amigo e poeta Murilo Mendes atribui a conversão ao catolicismo de ambos à influência que neles exerceram a pessoa, a arte e o pensamento religioso de Ismael Nery. A morte deste original pintor surrealista, em 1934, teria sido decisiva para a criação do lema. "Restaurar a poesia em Cristo", que presidiu a composição de Tempo e eternidade. O livro traz poemas de Jorge de Lima e de Murilo Mendes centrados em princípios de um fervoroso catolicismo e vazados em imagens do Antigo e do Novo Testamento. Mas, ao passo que são numerosos e reveladores os depoimentos que Murilo Mendes (1996) deixou encarecendo a presença de Ismael Nery na sua concepção de vida e de poesia, o testemunho de Jorge de Lima é escasso, embora expressivo. ${ }^{1}$ Lembro a dedicatória de Tempo e eternidade e a criação de Pintura em pânico, livro de fotomontagens certamente inspirado nos procedimentos artísticos de Nery. E esta referência, colhida em entrevista a Homero Sena:

Pois num simples verso de Ismael Nery, que você pode ler aqui neste outro livro - "Meu Deus, para que puseste tantas almas num só corpo?" - sente-se a influência do escritor italiano [Pirandello]: após a fragmentação da personalidade, a tragédia de reconstituição da unidade, quando no mesmo poema exclama:

Ó Deus estranho e misterioso, que só agora compreendo! Dai-me, como Vós tendes, o poder de criar corpos para as minhas almas. (Lima, 1985b, p.85)

Como pensador, Ismael Nery concebeu um sistema que Murilo Mendes (1996, p.47-54) batizou de "essencialismo". Não cabe aqui sequer tentar resumi-lo, o que em parte já foi feito pelo próprio Murilo de modo exemplarmente didático. Ao menos dois de seus princípios centrais parece-me que estão presentes, sob as espécies de imagens, na poesia religiosa de Jorge de Lima encetada pelos poemas de Tempo e eternidade e desdobrada em A túnica inconsútil e em Anunciação e encontro de Mira-Celi.

O primeiro e mais fecundo princípio é o da "abstração do tempo e do espaço". A matriz dessa suspensão de ambas as categorias é mística e encontra-se numa reflexão de Mestre Eckhart:

Não há maior obstáculo para a alma, quando ela quer conhecer a Deus, do que o tempo e o espaço. O tempo e o espaço, com efeito, não passam de partes, enquanto Deus é a unidade. Para que a alma possa conhecer a Deus, é preciso que ela o conheça além do tempo e do espaço, porque Deus não é nem isto nem aquilo, como estas coisas diversas. Deus é Unidade. (apud Mendes, 1996, p.139)

Nas palavras de Jorge de Lima: "Não me conformo nem com o espaço nem com o tempo. Nem com o limite de coisa alguma". E adiante: "Ismael explicava-nos sua vocação divina, sua inconformidade com o tempo e o espaço, a irreprimível necessidade que sentia de estar em todos os lugares ao mesmo tempo".

O segundo princípio, que Jorge de Lima já reconhecera no teatro de Pirandello, é o da multiplicidade inerente no interior de cada pessoa: as muitas 
almas em um só corpo, e seu constante movimento, o que dá origem a combinações e metamorfoses surpreendentes. Processos surrealistas como deslocamentos, condensações e colagens constelam a expressão poética desse motivo recorrente no pensamento de Ismael Nery.

É claro que não se deve reduzir a princípios abstratos a obra de Jorge de Lima escrita com o fim explícito de restaurar a poesia em Cristo. Entre o conceito e a forma poética, quantas mediações de imagem e de som! Mediações que são parte da força da imaginação e da música difusa nesse extraordinário poeta lírico.

De todo modo, há convergência no trabalho de significação que envolve a intencionalidade dos motivos e temas. Na escrita singular de Jorge de Lima a suspensão do tempo em face da intuição da eternidade não decai à recusa maniqueísta do momento concretamente vivido pela natureza e pelo homem. Há sublimação, mas não há a tentativa inglória de supressão radical do espaço-tempo, a qual, de resto, teria inibido o afloramento de toda e qualquer imagem... A propósito, convém ler as agudas observações de Roger Bastide (1997, p.11941 ) a respeito da conservação das fontes populares e, especialmente, negras na poesia religiosa e metafísica de Jorge de Lima.

O cosmos, criado por um Deus generoso, esplende nos versos de "Distribuição da Poesia", sem que a beleza que dele emana, e que o poeta oferece ao Senhor, deixe de resistir no tempo e no espaço. Pelo contrário, a criação se dá ao poeta de forma sincrônica: a simultaneidade das imagens evocadas mimetiza o sentimento do perene que transcende a fugacidade dos momentos sucessivos no tempo do relógio. Em outras palavras: a eternidade supera - conservando dialeticamente - o tempo. Glosando a sentença tomista, se a alma supõe a existência material do corpo, a eternidade supõe a vigência do tempo: "Mel silvestre tirei das plantas/ sal tirei das águas, / luz tirei do céu./ Escutai, meus irmãos: poesia tirei de tudo para oferecer ao Senhor".

De todo modo sempre subsiste, depois da Queda, o "mundo", na acepção joanina de locus originário do mal e da morte, da iniquidade e do medo, e, como tal, também pesa em alguns poemas como noturno caos, o outro lado do cosmos luminoso: "Capitão-mor, que noite escura/ desabou neste cais/ desabou neste caos!".

Cosmos de luz e caos trevoso convivem ora no regime do tempo, que de repente passa e muda de figura, ora ansiando pela irrupção do eterno, de onde procede a salvação bíblica e cristã.

Os símbolos do tempo voraz são diversos: o vento, motivo recorrente de toda a poesia de Jorge de Lima, e que anima o mais belo dos poemas de Tempo e eternidade, "Na carreira do vento"; a tormenta, que tudo arrasa e a todos apavora; a tarde oculta em um "tempo" sem tempo, infinitamente vasto, onde os horizontes são as nuvens que fogem...; as estrelas já mortas, mas ainda cintilantes na noite escura, espaço negro e vazio, contíguo e contrário ao "sono iluminado 
que Deus me deu antes de me criar". Coexistem tensamente esses fenômenos mutáveis do Tempo e o mistério do homem destinado ao infinito.

"Obrigado, ó mortos. Da noite que vim/ pra noite que vou/ relâmpago de Deus - sou.” Ou: "Carne não me satisfaz./Não conheço coisas necessárias. / Tudo é casual neste charco. / Quero ser ensinado por Deus”.

E há poemas em que é a oposição que avulta e torna-se agônica: “O poeta vence o tempo", “O poeta diante de Deus", "Os voos eram fora do tempo", "Adeus, poesia".

Era de esperar que essa tensão entrasse também no reino deste mundo na forma de profecias apocalípticas. A História nos últimos dias será julgada para dar lugar à Parusia: "Eu vos anuncio a consolação" e "Sicut erat": "Não precisarás de ponteiros para marcar o tempo".

Quanto ao segundo princípio, inspirado, por hipótese, no essencialismo de Ismael Nery (a multiplicação das almas no corpo e a respectiva metamorfose na percepção dos seres) realiza-se em A túnica inconsútil e no poema de Mira-Celi. A túnica de Cristo é una, sem emendas, ao passo que as roupagens do mundo são, como o tempo, inúmeras, fragmentadas, díspares. Não será fácil, talvez nem sequer necessário, separar abstratamente os dois princípios assinalados, quando se lê um poema de A túnica inconsútil, "Poema do Cristão", que abre o livro. O descarte, que nele se opera, de toda ordem cronológica e de toda espacialização pontual combina-se com as transformações que sofrem os objetos da percepção. "A minha visão é universal/e tem dimensões que ninguém sabe./ Os milênios passados e os futuros/não me aturdem, porque nasço e nascerei,/porque sou uno com todas as criaturas,/com todos os seres, com todas as coisas/que eu decomponho e absorvo com os sentidos,/e compreendo com a inteligência/ configurada em Cristo."

A linguagem é assertiva, o tom é o de quem professa abertamente a sua crença e a subjetiva ao extremo: "estou molhado de limos primitivos/e ao mesmo tempo ressoo as trombetas finais (salto do Gênesis ao Apocalipse); opero transfusões de luz nos seres opacos".

Há poemas construídos em torno das mutações do cosmos: "Onde está o mar?”, “O novo poema do mar”, "A multiplicação das criaturas”, "O monumento votivo", já plenamente surrealista apesar do imaginário católico tradicional que o constitui, do mesmo modo que se vale extensamente de figuras do Velho Testamento o poema "Sabereis que corri atrás da estrela".

O livro, em virtude do forte veio programático que o permeia, tem altos e baixos. Talvez o ponto mais alto tenha sido alcançado na criação de um poema de estrutura narrativa saliente, "A ave", que, aliás, tem merecido a preferência da maioria dos seus leitores.

Diversamente de boa parte dos poemas longos de A túnica inconsútil, “A Ave" mantém cerrada unidade temática não se dispersando em figuras aleatórias que, às vezes, interrompem o fluxo semântico do texto. Aqui há uma imagem 
condutora, cuja presença lhe empresta o papel de verdadeira protagonista de uma narrativa bem articulada. Passo à glosa do texto.

Os atributos da ave são bem delineados. Ela é estranha, desconhecida de todos, até mesmo dos homens do mar e dos andarilhos. A sua descrição, porém, foge a qualquer denotação realista, pois "era antropomorfa como um anjo e silenciosa como qualquer poeta". A partir do décimo verso, "Primeiro pairou na grande cúpula do templo", a ave, embora habitante de outros climas, deseja entrar em contacto com o mundo dos homens. Pousa no lugar sagrado, de onde é tangida pelo sacerdote, assim como seria enxotada do farol, sem que ninguém quisesse alimentá-la ou sequer acolhê-la com benevolência. $\mathrm{O}$ poema avança pela dramatização da recusa: a ave é demonizada pelas mães que temem algum malefício que sobrevenha aos filhos, caso se abriguem à sombra das suas asas. Todos os males lhe são imputados: a enchente, a seca, a morte dos cordeiros. Negam-lhe até a água, e ela tomba em terra "como um Sansão sem vida".

Nos versos finais, a ave morta é descoberta por um pescador e santificada pela evocação dos benefícios que prestara em vida: levara ovos aos anacoretas, cedera as penas para o gibão do mendigo... Enfim, o chefe do povo reconhece-a como o rei das aves, "que desconhecemos". O final surpreende e comove pelo acento afetuoso das palavras ditas pelo filho mais moço do chefe: "Dai-me as penas para eu escrever a minha vida/ tão igual à da ave em que me vejo/ mais do que me vejo em ti, meu pai". Consuma-se a identificação que se segue à lembrança viva da ave morta. O jovem que assim fala era "sozinho e manso" como a ave rediviva no seu coração.

No contexto religioso de A túnica inconsútil, teríamos aqui uma alegoria da vida, paixão, morte de Cristo? É uma leitura possível, senão provável. Não faltam sinais de afinidade com a narrativa do Novo Testamento. A ave procede de uma "outra atmosfera", de um "outro mistério" e vem a este mundo. E "o mundo", como está dito na abertura do evangelho de João a respeito de Jesus, "não o conheceu". A rejeição é violenta por parte dos sumos sacerdotes que não toleram vê-lo pregando no templo, o expulsam e tentam lapidá-lo (João, 10, 31). A ave tem forma humana como antropomorfa é a divindade que, pela encarnação, "se fez homem e habitou entre nós" (João, 1, 14). Em ambas as narrativas, há o momento em que acusam o estranho de ter poderes demoníacos. Solitários e desamparados, ninguém lhes oferece abrigo, não tendo, como diz o Filho do Homem , onde repousar a cabeça (Mateus, 8, 9). E à ave... "ninguém lhe ofereceu um pedaço de pão, ou um gesto suave onde se dependurasse". A ave morreu de sede: uma das últimas palavras de Cristo na cruz foi "Tenho sede" (João, 19, 28). A ambos negaram água.

$\mathrm{Na}$ Escritura a ressurreição segue-se à morte. No poema, a ave morta ressurge na memória dos que receberam suas graças. Tardiamente, o chefe a reconhece como rei das aves, mas cabe a seu filho, "sozinho e manso", reconhecer-se a si mesmo na ave, mais do que na imagem do próprio pai: "Dá-me as penas 
para eu escrever a minha vida/ tão igual à da ave em que me vejo/ mais do que me vejo a ti, meu pai". Um ato de identificação gerado pelo amor e não pelo sangue.

O risco do pensamento alegórico é conhecido: trata-se de um procedimento comparativo que tende a fechar o universo da significação na medida em que remete a um "outro discurso", como ensina a etimologia mesma da palavra. O símbolo, em compensação, embora tenda igualmente a aproximar duas expressões diferentes mediante o escavamento de suas semelhanças, teria a faculdade de abrir-se a várias conotações. O pensamento simbolizador admite mais de uma significação possível, ao passo que a alegoria aperta os laços que, por hipótese, atam a imagem a um determinado conceito. Talvez não seja forçar os termos de uma definição dizer que a alegoria é uma variante concentrada e unidimensional do pensamento simbólico. Essas considerações têm por objetivo sugerir que pode haver outras interpretações de A Ave, que dariam ênfase a outros perfis do poema e a outras afinidades latentes. A questão se torna particularmente viva quando temos pela frente uma das obras mais enigmáticas de Jorge de Lima, Anunciação e encontro de Mira-Celi.

\section{Mira-Celi}

A decifração desse livro singular é tarefa difícil, mas o intérprete desnorteado consola-se de seu embaraço ao ler o artigo que Jorge de Lima escreveu para a revista Vamos Ler, em 16 de março de 1943, sob o título "Explicação de Mira-Celi". Começa dizendo: "Acho dificuldade de explicar à professora americana a vida de Mira-Celi. A vida, a origem, os jogos, o conhecimento dela, tudo inexplicável". O texto continua, dando a entender que se trata de uma entidade fugidia, vinda provavelmente da eternidade, e que aparece a seu bel-prazer, mas de preferência nos momentos de solidão e febre do poeta. A sua esquivança deixa o leitor perplexo e o convida a percorrer os 59 poemas que compõem o livro, e que dão a impressão de serem partes de um conjunto coeso, e não textos independentes.

No encalço de um motivo condutor, o que sugere aparência de unidade é a recorrente pergunta sobre a natureza mesma de Mira-Celi, questão afim à do significado que assume para o poeta.

O poema de número 2 abre-se com uma definição assertiva:

Tu és, ó Mira-Celi, a repercutida e o laitmotivo / que aparece ao longo do meu poema.

Cabe a interrogação: essa presença constante, que remete a um ser (um espírito, uma força natural ou sobrenatural) viveria, de algum modo, fora ou dentro do sujeito lírico? Ambas as condições de existência estão configuradas no poema:

Dentro: "Nele [no meu poema] estás construída à semelhança de um imenso órgão/ movimentado pelo meu espírito". 
Fora: "Ora és sacerdotisa, musa, louca ou apenas ave",

Dentro e fora:

Pouca gente encontrará a chave deste mistério./ E os olhos que perpassarem através de tantos poemas que não/ findam e que se transformam de momento a momento,/ não compreenderão o movimento perpétuo/ em que nos perseguimos e nos superpomos./ Outras vezes as minhas mãos são um disfarce de ti,/ escrevendo a tua história ou me sustentando a face.

Reversibilidade que, dependendo do contexto, aponta o eu como condição da existência de Mira-Celi, ou faz desta uma força transcendente que o toma de assalto e o inspira. Tangenciamos aqui uma das matrizes românticas e simbolistas da crença na inspiração como fonte inconsciente do poema. Se esta é uma das missões inegáveis de Mira-Celi, convém, sempre no clima da reversibilidade, distinguir dois vetores complementares da inspiração:

Mira-Celi é inspiração do poeta. Trata-se do procedimento sintático classificado como genitivo subjetivo: a inspiração provém do eu lírico, sua fonte e gênese nele demoram.

Na outra ponta, Mira-Celi é inspiração para o poeta, genitivo objetivo: o que transcende a pessoa do artista é força que a preenche e inspira. $\mathrm{O}$ transcendente vai ao encontro da imanência, o objeto norteia e guia o sujeito.

Nas palavras de Jorge de Lima, sempre mais fecundas do que a prosa que tenta interpretá-las: "Quase sempre te transformo para te distribuir / e quando me resta uma única migalha, reconstruo-te como uma catedral e alimento-te como uma criancinha".

Não creio que haja nesta multifacetada invocação de Mira-Celi margem para reduzi-la à figura da Musa ou a alguma outra alegoria unidimensional. Mesmo quando o poeta a chama abertamente de "cristocêntrica", como o faz no quinto poema, a polivalência simbólica rege o apelo a essa figura, que reaparecerá em mais de uma passagem de Invenção de Orfeu. De certo modo, o sentido do transcendente calado na História lembra a síntese de Teilhard de Chardin, pela qual o cosmos se move na direção do ponto ômega da consciência em Cristo:

Quando te aproximas do mundo, Mira-Celi, /sinto a sarça de Deus arder em círculo, sobre mim. (poema 6)

Há quantos milênios bate no meu barro o vosso diapasão de luz? / Adonai, vejo presenças nas ventanias. / são vossas mãos por acaso ou vossa túnica multiplicada,/ ou apenas Mira-Celi, a de fogo e música, a reclusa e onipresente? (poema 50)

\section{Livro de sonetos}

Dois caminhos concorrem para desvendar os significados expressos ao longo do Livro dos sonetos. Pode-se começar pelo mais viável: a procura dos motivos recorrentes que formam, às vezes, breves ciclos temáticos. Um exemplo feliz desse procedimento é o estudo de Ana Maria Paulino (1995), que se detém no 
exame de núcleos semânticos, de resto disseminados em quase todas as obras de Jorge de Lima: sono e sonho, memória da infância, mar, morte, musa, candeeiro...

O elenco poderia enriquecer-se com outros apoios referenciais que constelam o amplo imaginário do poeta: a noite, as ilhas, as aves, o galo, cavalos encantados, a lâmpada marinha, a rosa, a bem-amada, a eterna infanta... Os riscos eventuais desse caminho (o que não impede de percorrê-lo) são os desvios de rota que nos fazem cair na dispersão analítica ou na exegese do todo a partir do fragmento.

O outro modo de ler o Livro de sonetos é aprofundar a análise da forma viva interna que anima cada motivo e lhe concede o estatuto de criação poética. Trata-se aqui do conbecimento da imagem. No seu ensaio denso e arguto, $O$ engenheiro noturno, Fábio de Souza Andrade (1997) elegeu essa estrada real que o conduziu a uma interpretação original do Livro de Sonetos e Invenção de Orfeu.

Considerando os vetores de cada um dos métodos, pode-se concluir que ambos acabam construindo um todo indivisível. Imaginário e imagem, o universo figural do poema e o seu procedimento estruturante remetem um ao outro na hora da interpretação do texto. A sua estreita afinidade tem por matriz "a rainha das faculdades da alma”, expressão com que Baudelaire define a imaginação.

Sigo de perto algumas passagens do poeta-crítico extraídas de suas "Curiosidades estéticas":

Misteriosa faculdade esta rainha das faculdades! Ela afeta todas as outras; ela as excita, leva-as ao combate. [...] Ela é a análise, ela é a síntese; e no entanto homens peritos na análise e suficientemente aptos para fazer um resumo podem ser desprovidos de imaginação. Ela é isso, mas não é completamente isso. É a sensibilidade e contudo há pessoas muito sensíveis, demasiado sensíveis talvez, que dela carecem. Foi a imaginação que ensinou ao homem o sentido moral da cor, do contorno, do som e do perfume. Ela criou, no começo do mundo, a analogia e a metáfora. Ela decompõe toda a criação, e, com os materiais acumulados e dispostos segundo regras cuja origem só se pode encontrar no mais fundo da alma, ela cria um mundo novo, produz a sensação do novo. Como ela criou o mundo (pode-se decerto dizê-lo, até mesmo em um sentido religioso), é justo que ela o governe. [...]

A imaginação é a rainha do verdadeiro, e o possível é uma das províncias do verdadeiro. Ela é positivamente aparentada com o infinito. [...]

\section{O governo da imaginação}

Ontem à noite, depois de ter enviado as últimas páginas de minha carta, em que eu havia escrito, mas não sem certa timidez: Como a imaginação criou o mundo, ela o governa, eu folheava a Face nocturne de la Nature, e me deparei com estas linhas, que cito unicamente porque são a perífrase justificativa da linha que me inquietava: "By imagination, I do not simply mean the common notion implied by that much abused word, which is only fancy, but the constructive imagination, which is much higher function, and which, in as much the man is 
made in the likeness of God, bears a distinct relation to the sublime power by which the Creator projects, creates and upholds his universe." Por imaginação eu não quero somente exprimir a ideia comum implicada na palavra de que se faz tão grande abuso, a qual é simplesmente fantasia, mas justamente a imaginação criadora [note-se como Baudelaire traduziu o original inglês "constructive" $\mathrm{AB}$ ), que é uma função muito mais elevada, e que, na medida em que o homem é feito à semelhança de Deus, guarda uma relação distinta com essa potência sublime pela qual o Criador concebe, cria e mantém esse universo. (Baudelaire, 1951, p.764-72)

Baudelaire retoma e salienta a distinção originariamente romântica entre a imaginação reprodutiva, colada à representação do real, e a imaginação produtiva, que o texto inglês chama "construtiva", e que o poeta traduz como "criadora". Se atentarmos para a qualidade da imagem presente no Livro dos sonetos, concluiremos, à primeira vista, que é essa última que constitui o procedimento corrente em quase toda obra. Jorge de Lima constrói sistematicamente o que Baudelaire considera criação de um mundo novo, tão verdadeiro como o que nos é dado pela percepção cotidiana.

Não me deterei aqui na rede de influências ou afinidades desse potenciamento da imagem inerente à poesia de Jorge de Lima. Romantismo, simbolismo, expressionismo (no caso da sua pintura), surrealismo, hermetismo e até mesmo barroco, tudo permeado de ardente fé cristã: eis os movimentos literários e culturais que tem sido assinalados para situar o poeta na história da cultura brasileira e, lato sensu, ocidental. Creio que será sempre plausível descobrir no seu itinerário poético traços deste ou daquele estilo de época. Romântica é a sua aberta preferência pela expressão das instâncias subjetivas ou líricas da poesia. Simbolista o tom solene e a dicção elevada dos sonetos. Surrealista a atmosfera onírica e febril, bem como o procedimento de colagem das figuras que aparenta a poesia e as fotomontagens. Hermético é o sentido difícil de precisar de tantas de suas aproximações verbais aparentemente aleatórias. Enfim, barroca seria a própria proliferação de imagens, analogias e metáforas que vai em crescendo do Livro dos sonetos até Invenção de Orfeu.

Mas à medida que se afunila o estudo do seu imaginário e dos seus meios estilísticos, deparamos com a voz singular de uma persona inconfundível. E esbatem-se no quadro do discurso crítico as classificações histórico-literárias e as tentativas de fazer tipologias psicanalíticas. Até mesmo a pertença do homem público Jorge de Lima a uma corrente renovadora do catolicismo social deve ser relativizada enquanto fator externo gerador de poesia. A chamada conversão de Jorge de Lima, simultânea à de Murilo Mendes, e confessadamente inspirada na religiosidade cristã de Ismael Nery, tem raízes no chamado "renouveau catholique", do primeiro quartel do século XX. Em termos literários, se expressou na poesia de Péguy, no romance de Bernanos e no teatro de Claudel. Ideologicamente só Péguy inclinou-se para o socialismo, e certamente vem dele a denúncia da exploração do proletário, que se encontra na poesia regional, negra e, a 
espaços, na vertente religiosa do nosso poeta. No entanto, seria forçar a mão estabelecer conexões estreitas entre a difusa mentalidade anticapitalista católica (encontrável também em alguns círculos ultraconservadores, aos quais Jorge de Lima nunca aderiu) e o imaginário entre místico e apocalíptico dos seus últimos livros.

A sua visão de mundo, expressão aqui mais adequada do que a sua ideologia, tem a ver com os dogmas centrais do catolicismo ortodoxo: o "mundo" e o "reino deste mundo" estão contaminados pela Queda, enquanto universo da violência, do poder e da iniquidade. Desse magma obscuro, de que o demônio é o príncipe, veio salvar-nos Cristo, Filho de Deus e Filho do homem (ambas as denominações constam nos evangelhos), mediante a graça concedida a todos os homens de boa vontade. Mas este mundo e o reino de Deus estão misturados, de onde a perene contradição em que se debatem todas as gerações. No último horizonte há a perspectiva de um juízo final, precedido de anos apocalípticos, nos quais homem e natureza padecerão de males devastadores.

O simples enunciado dessa revelação é o bastante para compreender o vetor suprapolítico (embora não necessariamente apolítico) da esperança escatológica, voltada para um tempo de redenção que rematará a história sofrida da humanidade. Nessa ordem de considerações, entende-se também o teor visionário de tantas imagens constantes do Livro de sonetos. Imaginação produtiva, construtiva e criadora, segundo as reflexões de Baudelaire, na medida em que se trata de imagens concebidas pela visão de um futuro inteiramente constituído pelo desejo (ou pela aversão) do poeta. O que não lhes tira a qualidade de reais, se é verdade que toda imagem denota algum fenômeno percebido ou rememorado. Cabe aqui uma observação sobre dois sentidos da palavra visão: faculdade de ver os objetos do mundo exterior, sinônimo de percepção realista; e aparecimento, epifania, que pode ocorrer com seres anômalos ou extraordinários, videntes, visionários, santos... e alguns artistas e poetas. Essa bivalência do termo visão remete à dualidade do termo "imagem", que pode reportar-se, como se viu linhas acima, ora ao objeto da percepção comum, socializada, ora a uma intencional construção-criação da mente poética.

Entramos, nesta altura, em pleno debate entre realistas e surrealistas. Ancorados no trabalho da imaginação durante os sonhos e, complementarmente, no arbítrio do artista que faz colagens de corpos, cenas e quadros com vistas à produção de novas figuras, os surrealistas preconizam literalmente a criação de uma nova e suprarrealidade. Para tanto, faz-se necessário que a imaginação se valha das percepções da vigília ou do devaneio para combiná-las, desconstruí-las e reconstruí-las como um novo demiurgo que tira da sua vontade e do inconsciente mundos paralelos ao do bom senso convencional. No limite, os efeitos desse processo combinatório podem despertar no leitor a suspeita de que se trata de um hermetismo programado, o que, no caso de Jorge de Lima, me pareceria um juízo equivocado. Prefiro atribuir a gênese da escrita enigmática em 
parte ao "estado hipnagógico" em que, em dois meses de febre e sedação, ele escreveu os 78 sonetos deste Livro repleto de visões, algumas alucinadas, outras dotadas de serena harmonia. ${ }^{2}$

No quarto soneto, "Sei Teu grito profundo...", a alma confessa ao Cristo crucificado (Ó Desnudado) o seu estado de derrelição. O motivo tem raízes na literatura mística do outono da Idade Média, de que a Imitação de Cristo é o mais perfeito modelo. A originalidade do soneto está na profusão de imagens, verdadeiras células metafóricas. A alma sabe-se presa à raiz divina da qual tudo recebeu: origem, patas, asas, enumeração insólita, que aproxima a gravidade animal das patas e a graça aérea das asas, atributos contraditórios do ser decaído e redimido. Não se detém aí a imaginação construtiva do poeta: ele compara-se à "pobre enguia de águas rasas", ao passo que de Cristo diz que é o "Nazareno dos lagos e lume primo", reunindo pecador e redentor mediante a parábola evangélica do joio misturado ao trigo até que o Juízo Final os separe. O fecho é à primeira vista hermético: "Ó Desnudado! é meu todo o disfarce/em revelar os tempos que persigo/- na vazante maré com inversa proa". A alma, diferentemente da divindade que nada oculta, dissimula (disfarça) a sua condição de homem vivendo à mercê da corrente do tempo e encalhado na maré baixa em barco sem norte (inversa proa).

A face temível dos tempos derradeiros está manifesta em um soneto coesamente armado: "Se a estrela de absinto desabar". Todos os signos, concebidos por uma imaginação febril, prenunciam a agonia do universo. Nenhuma glosa prosaica pode substituir a leitura integral do soneto:

Se a estrela de absinto desabar terei pena das águas sempre vivas porque um torpor virá do céu ao mar amortecer o pêndulo das vidas.

Sob o livor da morte coisas idas já são as coisas deste mundo. No ar as vozes claras, tristes e exauridas. Há sombras ocultando a luz solar.

Galopes surdos, cascos como goma. Viscosos seres, dedos de medusas Contando silenciosos coisas nulas.

Verdoengo e mole um ser estranho soma:

Crânios como algas, vísceras confusas, massas embranquecidas de medulas. 
As sonoridades escuras, surdas, cavas, em sintonia com o lívido torpor das imagens provêm da peculiar condição do poeta, médico de enfermos terminais, debruçado sobre corpos na decomposição da agonia, e crente visionário das cenas figuradas no Apocalipse de João, também chamado Livro da Revelação. ${ }^{3}$

Não se trata, evidentemente, de um texto isolado. O mesmo pressentimento de uma hora fatal, convertida em tempo de agora pelo poder da visão, aproxima quatro sonetos seguidos.

"O horizonte era estreito", que termina assim: "O oceano apodreceu no próprio leito,/ e uma lava comum, estranha lava/de loucura inundou bestas e gênios"; o soneto "O mundo estanque, o céu alucinado,/o olhar vítreo de Deus furando o tempo"; o soneto "Tudo estancara. Eu mesmo. Do alto vi-me"; e "Sentado em pirâmides vulgares", cujo terceto final trai o desejo de ver a catástrofe universal: "Quero assistir ao trágico desfecho/desse último espetáculo encantado /que irá encher espaço, terra e mares".

A concorrência de visão e transformação move-se no limite do que seria uma poética surrealista difusa no Livro de sonetos. É o que sugere o soneto "A torre de marfim, a torre alada" na procissão de imagens em perpétuo movimento:

A torre de marfim, a torre alada, esguia e cinza sob o céu cinzento, corredores de bruma congelada, galerias de sombras e lamentos.

A torre de marfim fez-se esqueleto E o esqueleto desfez-se num momento, Ó! Não julgueis as coisas pelo aspecto, que as coisas mudam como muda o vento.

E com o vento revive o que era inerme.

Os peixes também podem criar asas, as asas brancas podem gerar vermes.

Olhei a torre de marfim exangue

e vi a torre transformar-se em brasa

e a brasa rubra transformar-se em sangue.

O anúncio do desfecho de toda a história não é única missão do poeta visionário. Há também a hora de contemplar a luta que se trava no meio do caminho. O soneto "Há cavalos noturnos, mel e fel" sobressai pela densa concisão com que trabalha o tema do embate das forças do bem e do mal, unindo 
a imagem sobrenatural do Arcanjo Miguel com o ícone do grande visionário da tradição literária, o Quixote de Miguel de Cervantes.

Há cavalos noturnos: mel e fel.

O cavalo que vai com Satanás

e o cavalo que vai com São Miguel.

O cavalo do santo vai atrás,

e vai na frente a azêmola cruel.

Mas vão os dois e cada qual com um ás.

No cavalo da frente o atro anjo infiel

com façanhas de guerra se compraz.

São Miguel de la Mancha, D. Quixote,

Garcia Lorca viu-te, vejo-te eu

na luta igual com o ás da negação,

arremeter com lança em riste e archote.

E ao fim de tudo há um anjo que venceu:

Tu, D. Quixote da Anunciação.

Algumas observações tópicas:

"Há cavalos noturnos: mel e fel". Mel e fel - a suprema doçura e o amargor extremo, contrários e contíguos na vida e no verso. Bem e mal cavalgam na noite, pois os cavalos são noturnos e escura é a travessia em que transcorre a história dos homens.

Adiante, com a sobriedade da denotação clássica, vêm os nomes dos cavaleiros. São dois anjos: aquele a quem foi dada a primazia no governo do mundo, Lúcifer, degradado em Satanás; e aquele que luta contra os poderes das trevas, audaz, mas sem violência, São Miguel.

"O cavalo do santo vai atrás". Indício da arrogância e açodamento do Mal ou sinal da primazia do tentador durante o percurso que nos foi traçado entre o nascer e o morrer? Haverá alguma ênfase intencional neste enunciado da posição dos ginetes. A rigor, não seria logicamente necessário dizer que vai na frente a azêmola cruel. Mas quanto se perderia se fosse omitida a palavra árabe, rara e expressiva, que marcou, desde a Idade Média, a inferioridade da raça, sendo azêmola sinônimo de besta, animal rude e tosco, se comparado à fiel nobreza do corcel!

"Mas vão os dois e cada qual com um ás". A disparidade das montarias é contrabalançada pelo valor atribuído aos cavaleiros. A conjunção "mas" adverte que cada um ostenta a mesma qualidade mestra de ás. A diferença, porém, re- 
ponta, e é tudo. O cavaleiro da frente, com ser anjo, é não só atro como infiel, enquanto transgressor da lei divina e causa da queda das primeiras criaturas.

"Infiel" traz em si os fonemas de fel. A rima final do segundo quarteto (ás-compraz) é um achado semântico-sonoro, denunciando o ânimo belicoso do anjo do Mal que com façanhas de guerra se compraz.

Os tercetos dizem, dentro de um período fortemente articulado, o essencial do combate. $\mathrm{O}$ arcanjo Miguel desce da transcendência para entrar na alma do criador do mais puro dos cavaleiros. É São Miguel de la Mancha (assim nomeado, em castelhano), incorporado, por meio de um aposto, à sua inseparável criatura, Dom Quixote.

O poeta irmana-se com outro grande poeta da Espanha, Garcia Lorca, na sua visão do arcanjo figurada no Romancero Gitano ( "Garcia Lorca viu-te, vejo-te eu"). Um deslocamento temporal avizinha a luta de São Miguel com os feitos do Quixote, "que arremete com lança em riste e archote" contra o "ás da negação".

Na hora da vitória final, a identificação é explícita: "E ao fim de tudo há um anjo que venceu: Tu, D. Quixote da Anunciação”.

Por um equívoco feliz, ou escolha voluntária, Jorge de Lima atribui ao Arcanjo Miguel a missão de anunciar à Virgem Maria que ela dará a luz ao Messias, o que, no texto evangélico, é confiado ao Arcanjo Gabriel (Lucas, 1, 26). De todo modo, o que importa é o gesto poético de fundir a imagem do anjo lutador com a do Cavaleiro da Mancha, deixando implícito que se trata de combatentes fiéis, refratários à violência. De um lado, a serena nobreza de Miguel que, segundo a Epístola de São Judas $(1,9)$, vence o Maligno, mas abstém-se de injuriá-lo e infamá-lo ("finge una cólera dulce", diz Lorca ao descobri-lo em um altar cigano); de outro lado, a alma alevantada do Quixote, incapaz do mínimo ato de egoísmo ou vilania, percorrendo o mundo para restaurar a justiça e o respeito violados por inimigos ignóbeis.

\section{Junto às fontes da lírica: a infância, a amada}

Não só de visões transcendentes e do embate entre o Bem e o Mal extrai Jorge de Lima a matéria-prima do Livro de sonetos. Sendo um poeta eminentemente lírico, a sua imaginação também desce ao próprio passado e, como nas primeiras obras afetadas pelo modernismo regionalista, traz da infância motivos condutores de mais de um poema.

Embora o Livro de Sonetos não se disponha em ordem narrativa ou temática, não deixa de ser digno de nota o fato de os sonetos da infância virem só no último terço da série. Mas, quando chegam, é como se emergissem, um após outro, jorrando do poço da memória prestes a transbordar. As figuras evocadas passam a ter nome e história e o desejo de fixá-las modula-se ora em forma interrogativa ("Onde está o Marão?”), ora em torneios puramente narrativos: "/ Eu fui de lá. Minha avó era fiandeira. Ouvi romances./ Chorei Páscoas, nadei por vários poços"; ora, enfim, com entoação exclamativa: “Ó meninos, ó noites, ó sobrados!" Este último verso repete o final de outro soneto evocativo: 
Nas noites enluaradas cabeleiras

das moças debruçadas, dos sobrados

desciam como gatas borralheiras

por sobre os nossos lábios descuidados.

Talvez seja possível estender à criação poética o que a observação empírica nos sugere em termos da insistente repetição com que figuras e cenas da infância acorrem à mente do adulto. No imaginário evocativo da meninice Jorge de Lima alcança um alto nível de redundância. Palavras, frases, às vezes períodos inteiros assinalam a presença obsessiva de seres que povoaram os seus primeiros anos em Alagoas. De tudo faz o poeta matéria de poesia: noites enluaradas, meninas e meninos no sobrado, o avô morto, a avó fiandeira, a draga na maré baixa ("Lembras-te, meu irmão, da draga morta?"), o Marão, onde o menino mourejou, a esfera armilar e o candeeiro antigo, os galos e o seu canto. Mas, de repente, a névoa da memória...

Ao lado da nítida rememoração surge o encontro com o tempo roaz, irreversível. É o risco do esquecimento, a queda no vazio que assombra, quando não apaga cada figura e cada cena vivida nos verdes anos. Neste soneto o desaparecimento do passado atinge não só a história familiar, mas também a dos nautas e descobridores lusitanos, de onde o intertexto camoniano, que voltará em mais de um passo da Invenção de Orfeu:

Virado para o Marão o avô morrido/ e o pai deste Nordeste sepultado./ Rio Lima e Mundaú. O filho nado/ em limo e sal do mar sobrevivido.// Nem da roda de fiar da avó, o ouvido/ conserva do som. Silêncio. O céu calado./Descobridor do oceano submergido,/ navegante do rio emparedado.// Sôbolos rios e sôbolos oceanos,/ só uma sombra de nauta fragmentada/ no roteiro dos mares lusitanos.//O restante é oceania naufragada:/cavernas de nau, âncoras e gáveas./ Dessa vasa salobra a morte lave-as.

Enfim, o melos, a música da lírica amorosa, que nos sonetos é pouca, mas intensa, pois testemunha o desejo sublimado de tornar presente a amada para sempre ausente:

E esta angústia de te recompor, traço

a traço, tua boca dolorosa

(fonte que se exauriu), teu rosto escasso,

ó musa angelical, airosa rosa!

Quando li, pela primeira vez, os sonetos da amada ausente, figurada na imagem enigmática da infanta defunta, veio-me à memória a poesia de amor, igualmente sublimado, de Alphonsus de Guimaraens. O sentimento de fundo é o mesmo, semelhante é a forma clássica dos decassílabos, idêntico o procedimento que evita a descrição precisa preferindo a "melodiosa dança" das aparên- 
cias fugidias, inapreensíveis. Refiro-me à coletânea de 77 sonetos incluídos na obra póstuma do poeta de Mariana, Pastoral aos crentes do amor e da morte.

Mas é a diferença que contribui para compreender melhor o substrato lírico do Livro de Jorge de Lima. Alphonsus compôs um cancioneiro fiel à tradição petrarquista e camoniana. A crítica biográfica reconheceu de pronto na figura de Constança, morta em pleno noivado, a inspiração e o motivo recorrente da melhor lírica do poeta. Mas o eterno feminino dos sonetos de Jorge de Lima não se submete a nenhuma determinação realista sendo infenso a descrições psicológicas. Musa, Mira-Celi ou infanta, é a indeterminação que rege a sua fisionomia. Essa condição favorece uma escrita antes surrealista do que romântica ou simbolista. E dá ao poeta a liberdade de trabalhar a móvel imagem da amada valendo-se do seu recurso congenial de metamorfose do objeto trazido ao círculo do sujeito.

É surpreendente a riqueza da imaginação metafórica que nomeia os perfis da amada: "lâmpada marinha, oculta rosa, airosa rosa, viva e impossível, suave névoa erradia, desmanchada rosa irreal, eterna bem-amada, lâmpada única, ogiva a orar na sombra desvairada, lírio ardido, senda de elevação, vida minha, estrela do viajor, túnica sonora, laguna quieta sob luas mansas, ensimesmada musa conjurada, sonâmbula, borralheira transfigurada em bela adormecida, sombra escrava, sombra irmã, sortilégio, escada submarina, andarilha, Virgem ao mesmo tempo avó, mãe e filha, salamandra de asas, Ofélia, ubíqua e intemporal (note-se a recorrente suspensão das marcas espaciais e temporais), estátua cega, sacerdotisa e musa em desvario, poema sempre começado..."

Só a atmosfera onírica que envolve e penetra essas e outras tantas expressões, situando-as no seu contexto, pode dar a medida do encanto que suscita a leitura corrente dos sonetos. E se os versos forem pronunciados em voz alta, à guisa de interpretação, esses mesmos epítetos se disporão no ritmo e na entoação que os torna singularmente expressivos. Jorge de Lima é um dos poetas mais musicais de toda a literatura em língua portuguesa. O soneto com que termino este esquema de leitura dá testemunho de uma poesia em perpétuo movimento:

Essa pavana é para uma defunta infanta, bem-amada, ungida e santa, e que foi encontrada num profundo sepulcro recoberto pelos ramos

de salgueiros silvestres para nunca ser retirada desse leito estranho em que repousa ouvindo essa pavana recomeçada sempre sem descanso, 


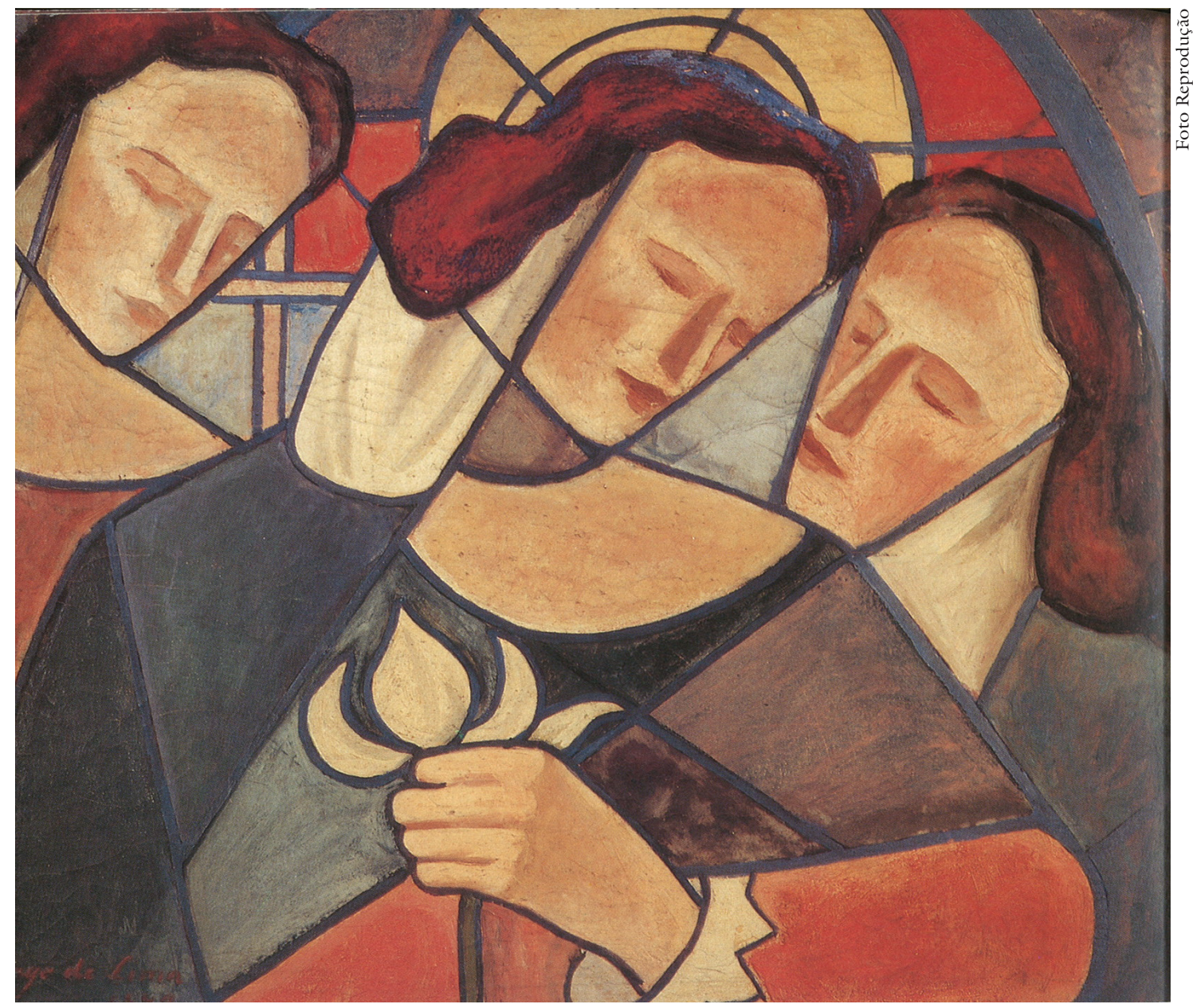

A imagem reproduz o quadro de Jorge de Lima, Vitral, 1947. A reprodução está no livro de Ana Maria Paulino, Jorge de Lima (São Paulo: Edusp, 1995).

sem consolo, através dos desenganos, dos reveses e obstáculos da vida, das ventanias que se insurgem contra

a chama inapagada, a eterna chama que anima esta defunta infanta ungida e bem-amada e para sempre santa. 


\section{Notas}

1 O leitor encontrará textos de memória e interpretação da pessoa e da arte de Ismael Nery na obra coletiva, Ismael Nery, 50 anos depois, editada pelo Museu de Arte Contemporânea da Universidade de São Paulo, em 1984. Agradeço a Murilo Marcondes de Moura a gentileza da informação e do acesso à obra.

2 Observação de José Fernando Carneiro (1958, p.48), médico do poeta.

3 Recomendo a leitura da acurada análise desse soneto em O engenheiro noturno, de Fábio de Souza Andrade (1997, p.99-105). Outro exemplo de leitura em profundidade encontra-se no ensaio de Mirella Márcia Longo (2015, p.341-56)

\section{Referências}

ANDRADE, F. de S. O engenbeiro noturno. A Lírica Final de Jorge de Lima. Prefácio de Davi Arrigucci Jr. São Paulo: Edusp, 1997.

BASTIDE, R. Poetas do Brasil. Prefácio de Antonio Candido. 2.ed. São Paulo: Edusp; Duas Cidades, 1997.

BAUDELAIRE, C. Oeuvres. Paris: Gallimard, 1951.

CAMILO, V. Jorge de Lima no contexto da poesia negra americana. Estudos Avançados, São Paulo, n.76 e 77, set.-dez. 2012; jan.-abr. 2013.

CARnEIRO, J. F. Apresentação de Jorge de Lima. Rio de Janeiro: Agir, 1958

LIMA, J. de. Minhas memórias. In: __ . Obra completa, I. Rio de Janeiro: José Aguilar, 1958a. p.98-157.

Autorretrato. In: __. Obra completa, I. Rio de Janeiro: José Aguilar, 1958b. p.85.

LONGO, M. M. A mão e a luva: a respeito de um soneto escrito por Jorge de Lima. Estudos Avançados, São Paulo, n.85, p.341-56, set.-dez. 2015.

MENDES, M. Recordações de Ismael Nery. Prefácio de Davi Arrigucci Jr. 2.ed. São Paulo: Edusp/Giordano, 1996.

PAULINO, A. M. Jorge de Lima. São Paulo: Edusp, 1995.

SARTRE, J.-P. L'imagination. 6.ed. Paris: PUF, 1965.

RESUMO - O ensaio visa percorrer o itinerário poético de Jorge de Lima desde a publicação do poema "O mundo do menino impossível" até o Livro de sonetos. Após a passagem do estilo acadêmico-parnasiano para a linguagem modernista Jorge de Lima voltou-se para a evocação da paisagem social de sua província natal, Alagoas. Nos anos 1930 escreveu poemas afro-nordestinos reunidos, mais tarde, nos Poemas negros. A partir da sua conversão ao catolicismo, sob a influência do pintor Ismael Nery, a sua poesia é abertamente bíblica e cristã começando com Tempo e eternidade composto em parceria com Murilo Mendes. Túnica inconsútil e Anunciação e encontro com Mira-Celi aprofundam a sua tendência mística. O Livro de sonetos exprime, em formas clássicas, uma imaginação surrealista. A compreensão do dinamismo das imagens é um dos motivos condutores do ensaio. 
PALAVRAS-CHAVE: Jorge de Lima, Poesia regionalista, Poesia negra, Surrealismo, Imaginação criadora.

ABSTRACT - This essay explorers the poetic journey of Jorge de Lima, from the publication of the poem "O mundo do menino impossível" [The world of the impossible boy] to Livro de sonetos [Book of sonnets]. After transiting from the academic-Parnassian style to the modernist language, Jorge de Lima turned to evocations of the social landscape of his native province, Alagoas. In the 1930s, he wrote poems of African and Brazilian Northeast inspiration, later gathered in Poemas negros [Black poems]. After his conversion to Catholicism, under the influence of the painter Ismael Nery, his poetry became openly biblical and Christian, beginning with Tempo e eternidade [Time and eternity] composed in partnership with Murilo Mendes. Túnica inconsútil [Seamless robe] and Anunciação e encontro com Mira-Celi [Annunciation and encounter with Mira-Celi] deepen his mystical bent. His Livro de sonetos expresses in classical forms a surrealistic imagination. Understanding the dynamics of the poet's images is one of the leitmotifs of this essay.

KETWORDS: Jorge de Lima, Regionalist poetry, Black poetry, Surrealism, Creative imagination.

Alfredo Bosi é titular de Literatura Brasileira na Universidade de São Paulo e membro da Academia Brasileira de Letras. Publicou, entre outras obras, História concisa da literatura brasileira; O ser e o tempo da poesia; Céu, inferno; Dialética da colonização; Machado de Assis: o enigma do olhar; Literatura e resistência; Brás Cubas em três versões; Ideologia e contraideologia; e Entre a literatura e a história. É editor da revista Estudos Avançados. @- abosi@usp.br

Recebido em 22.2.2016 e aceito em 3.3.216.

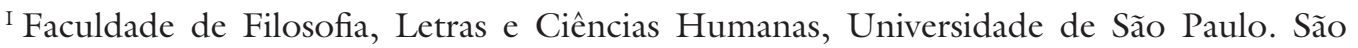
Paulo/São Paulo, Brasil. 
